\title{
Abundance of Pollinator Insect (Forcipomyia spp .) of Cocoa Under Some Shade Trees
}

\author{
Fakhrusy Zakariyya, ${ }^{1 *}$ Endang Sulistyowati ${ }^{1}$, and Dwi Suci Rahayu ${ }^{1)}$ \\ ${ }^{1)}$ Indonesian Coffee and Cocoa Research Institute, Jl. PB. Sudirman 90 Jember, Indonesia, dan 68118 \\ ${ }^{*}$ Corresponding author: fakhrusy.zakariyya@gmail.com \\ Received: 15 March 2016 / accepted: 23 June 2016
}

\begin{abstract}
Cocoa production is affected by cocoa flowering and fruiting. The factor affects fruit seeting is pollinator agent such as Forcipomyia spp. Until now, information concerning population dynamics of Forcipomyia in some models of cocoa shading trees remains limited. This research was studied to observe the population dynamics of Forcipomyia spp. in some models of cocoa shading trees, namely lamtoro (Leucaena sp.), krete (Cassia surithensis) and areca nut (Areca catechu) in two main season of rainy and dry seasons. The research was conducted in Kaliwining research station of Indonesian Coffee and Cocoa Research Institute (ICCRI), Jember, by surveying the existing cocoa under different types of shading trees as mentioned above. The insects were observed using modified sticky trap method, whilst micro climate condition was also observed. The highest population was in January (rainy season) under Leucaena spp. shade tress and the lowest population was in October under all type of the shading trees. There was no relationship between microclimate condition under cocoa trees (temperature, $\mathrm{RH}$ and light intensity) and Forcipomyia spp. population $(\mathrm{r}=0.08$ and 0.04$)$.
\end{abstract}

Keywords: cocoa, shades tree, population dynamics, Forcipomyia spp.

\section{INTRODUCTION}

Cocoa is one of Indonesian main commodities which play an important role in improving national economy. Currently, Indonesia is as the third largest cocoa exporter country after Ivory Coast and Ghana. However, average national cocoa productivity was only about 0.47 tons per hectare (Wahyudi \& Misnawi, 2015). In addition, opportunity to increase cocoa production is still possible, and also what strategies should be done in order to increase the cocoa production as well as the constraints that can be encountered. Using of shade trees in cocoa farm may solve the problem.

Cocoa cultivation requires shades, especially when the environmental conditions are less than the optimal condition, including farming management with relatively low input factors, such as limited availability of fertilizers and water (Prawoto et al., 2006). The shading plants for cocoa have some roles in several aspects, such as transmitted sunlight, temperature air humidity, nutrient availability and soil organic matter that may affect physiological processes of flowering and habitat of growing insect pollinators associated with the formation of the fruits (Prawoto, 2013; Evizal et al.,.2012). Moreover, number of cocoa flower may reach 6000 to 10000 buds per year, but only $2.5 \%$ of those flowers are pollinated (Kaufman, 1975); thus, the presence of insect pollinators is very essential. In some cocoa production areas, common shading plants which are 
used in the cocoa plantations are namely lamtoro (Leucaena spp.), gamal (Gliricidia sepium), coconut (Cocos nucifera), and areca nut (Areca catechu) (Prawoto, 2008).

Existence of shade trees serves as buffer and reducing the risk of extreme fluctuations of environment in the plantation production area due to climate change and the seasonal condition. The shade trees keep the environment in the farm remained stable (Prawoto, 2008). Moreover, it is able to keep the life cycle of the insect pollinators living optimally. Any information related to the effects of the shade trees to the insect pollinators have been discussed by Boreux et al. (2013) with the subject was that coffee plant which shows that the density of the protecting effect on pollinators due to litter and micro-climatic conditions ultimately affects the crop production. Fruiting set of the coffee berry can be increased more than $50 \%$ since it is pollinated by the insect pollinators (Ngo et al., 2011; Klein et al., 2003). Some researchers also noted that the number of fruit formation in plants determines the success of the production (Stephenson, 1981; Pias \& Guitian, 2006).

In cocoa, insect pollinators become the major factor given the structure of cocoa flower pollination has a very complicated structure (Adjaloo \& Oduro, 2013). There is only a small possibility that pollination occurs by the assistance of wind. Interest of insect pollinator which affects the pollination of cocoa has been reviewed by Kaufman (1974), who found that there were some insect pollinators of specific genus of Forcipomyia (Dipteral: Ceratopogoniidae) which were dominant contributing to natural pollination for cocoa. Population of Forcipomyia spp. also depends on climatic conditions of one region and also season in one particular area (Adjaloo \& Oduro, 2013). In addition, Ibrahim \& Hussein (1987) however explained that the difference in the microclimate, such as temperature and relative humidity in an area does not affect significantly on the population of Forcipomyia spp.

With the difference in shade trees, it is still uncertain that the dynamic population of Forcipomyia spp. in certain season and microclimatic condition is also different. However, cocoa flower pollination by insect pollinators is external factor that influences the formation of pods in cocoa (Winder, 1978; Stephenson, 1981; Bos et al., 2007; Omolaja et al., 2009). Research on cocoa insect pollinators, especially in Indonesia, has been widely studied in 1950's and 1980's, but it is still necessary to analyze current information related to this subject. The purpose of this study was to assess the abundance of insect pollinators Forcipomyia spp. in rainy season and dry season on cocoa under three shade trees namely lamtoro (Leucaena spp.), krete (Cassia surattensis), and areca nut (Areca catecu).

\section{MATERIALS AND METHODS}

This research was conducted in Kaliwining, Experimental Station of Indonesian Coffee and Cocoa Research Institute (ICCRI), Jember, East Java, with rainfall type of D (Schmidt \& Ferguson) with relatively flat topography at altitude $45 \mathrm{~m}$ asl. The study was conducted during dry season in August to November 2015, and rainy season within December 2015 to February 2016. Observations were made with the survey method on some models of shade trees of cocoa including lamtoro (Leucaena spp), krete (Cassia surattensis), and areca nut (Areca catechu). Cocoa plants used were bulk cocoa (Theobroma cacao L.) clones of Sulawesi 1 that was 6 years old in an area of 0.5 ha with the number of 500 plants. 
Insects were trapped by using modified sticky traps (Sulistyowati, 1986; Thompson et al., 2014) by modifying the color of the trap with a colored translucent plastic, and the insects were observed and monitored every two weeks. Sticky traps can be used for the activity of flying insects, especially from families Ceratopogoniidae for having hairy body so as to facilitate them being trapped. Sticky traps were placed between the rows (aisles) of cocoa trees at a height of $100 \mathrm{~cm}$ above the ground. There were ten traps $(n=10)$ which were placed randomly with the spread radius of 120 to $150 \mathrm{~cm}$ of cocoa under the shade trees. Sticky traps placed at 6 a.m. until 5 p.m. during peak insect activity (Adjalo \& Oduro, 2013).

Sticky traps are then identified in the Laboratory of Plant Protection, ICCRI in Jember East Java using a magnifying glass and a dissecting microscope at a magnification of 40x. Population was calculated by taking and observing one by one of the insect being stuck to each sticky trap and confirmed in accordance with the taxonomical morphology of Forcipomyia spp. based on Scudder \& Cannings (2006).

Microclimate conditions of temperature $\left({ }^{\circ} \mathrm{C}\right)$ and relative humidity (\%) were also measured by using a manual-type thermohygrometer A600FC. While the light intensity of the shade trees was measured using a digital luxmeter type. Data related to microclimate were obtained every two weeks during the study. The data were then summed to obtain the average point, and standard deviations were calculated. Data from the experimental plantation of Kaliwining are in the form of rainfall and the intensity of radiation taken at the weather station during the observation period. Statistical analysis of the parameters of the insect population every month was conducted by using analysis of variance with a confidence level of $95 \%$. If there is a real effect of the treatment followed by Tukey's test for further result $(\alpha=5 \%)$ (Gomez \& Gomez, 1984).

\section{RESULTS AND DISCUSSION}

The distribution of rainfall in the experimental plantation of Kaliwining can be seen in Table 1. The El Nino phenomenon in 2015 led to a dry months until October 2015. In 2015, it appeared that the dry months occurred in September, October, while the early November and December 2015 was shifting period in rainfall changes. Rainfall has increased dramatically as much as 64.9 to $73.7 \%$ in January and February 2016 with the rainfall of 340 and $453.7 \mathrm{~mm}$. The condition of light intensity in experimental plantation of Kaliwining showed that in September-November 2015 reached to 93-94\%, whereas within December to February, the light intensity was $64-82 \%$. Devoto et al. (2009) reported that the distribution and precipitation gradients may affect some kinds of life of the insect pollinators on agroforestry ecosystems in the southern part of South America. Additionally, Sulistyowati (1986) reported that Forcipomyia prefers calm and clear cloudy weather.

Table 1. Rainfall distribution and light intensity of Kaliwining Experimental Station during observation

\begin{tabular}{lcc}
\hline Month & Rainfall, mm & Days light, \% \\
\hline September & 0.0 & 94.6 \\
October & 5.5 & 92.1 \\
November & 120.7 & 93.5 \\
December & 119.3 & 68.9 \\
January & 340.0 & 82.9 \\
February & 453.7 & 64.7 \\
\hline
\end{tabular}


Based on the results of the study, it is suggested that the condition of the microclimate in each shade tree is different (Table 1). Higher temperatures occur in the shade of Leucaena for two seasons, although the intensity of the light that is not too high compared to Cassia surattensis and Areca catechu. However, the relative humidity (RH) tends to lows under the lamtoro tree for two seasons compared to the two other shade trees. The condition of the shade with a value of about $50 \%$ is ideal conditions for cocoa plants as reported by Acheampong et al. (2013).

Based on Table 2, shade tree Leucaena spp. has a shade the lowest light intensity compared to the other two shade trees. Shade tree lamtoro give $15-20 \%$ higher light intensity than Areca catechu and Cassia surattensis. It is supported by the statement Prawoto \& Sholeh (2006) that Leucaena spp. has a lower level shade than Areca catechu on certain plant spacing, although they still do not differ very much. The microclimate provides an overview of the ecology of the plantation so there is not any relation with organisms that grow either cocoa plants or insect pollinators (Young 1983; Young 1986; Adjalo \& Oduro, 2013; Regazoni et al., 2015).

Temperatures in the shade of Leucaena spp. was 1.5 to $2^{\circ} \mathrm{C}$ higher than the Cassia suratensis and Areca catechu. The temperature under the three shade trees showed decrease by 3.5 to $4^{\circ} \mathrm{C}$ from the dry season to the rainy season. This decline in temperature is followed by the rise in relative humidity under the three shade trees, where it was also accompanied by differences in the intensity of sunlight that went through the microenvironment plantation. In Leucaena spp. showed 4-5\% lower in the second season than the other two shade trees.

Insects trapped in the sticky traps were relatively diverse, but the species of flying insects that contribute to pollination was Forcipomyia spp. (Kaufmann, 1975). In the cocoa plantation, more female insects were trapped which were characterized by the antenna lint (Figure 1a.). Even though there were male insects of Forcipomyia spp. (Figure 1b.), were found in the plantation with brownish color with dense fur on its thorax and feet, and the size was 2 to $2.5 \mathrm{~mm}$ (Figure 1c). Nevertheless, it was still unclear about which species of Forcipomyia spp. which more exist in the cocoa plantations.

In general, Forcipomyia spp. consists of several species. Some insect species of this genus serves as natural pollinators. Forcipomyia hardyii and Forcipomyia quasiingramiare most commonly found in cocoa flowers. Kaufman (1975) mentioned that the insects that pollinate cacao flowers majority were female insects of Forcipomyia psinolataingrami, Forcipomyua falcinella, Forcipomyia ashantii and several other types.

Insects Forcipomyia spp. are reportedly to visit the cocoa flowers and collect the pollen by using the thorax part (back) which are equipped with hair feathers contained in the section. Forcipomyia spp. come visiting cacao flowers because of being allegedly interested in the red lines that exist in staminodes.

Table 2. Microclimate condition under different shade trees during dry and rainy season (Data \pm Standard of Deviation)

\begin{tabular}{|c|c|c|c|c|c|}
\hline \multirow{2}{*}{ Shade trees } & \multicolumn{2}{|c|}{ Dry season } & \multicolumn{2}{|c|}{ Rainy season } & \multirow{2}{*}{$\begin{array}{l}\text { Transmitted } \\
\text { sunlight, } \%\end{array}$} \\
\hline & Temperature, ${ }^{\circ} \mathrm{C}$ & $\mathrm{RH}, \%$ & Temperature, ${ }^{\circ} \mathrm{C}$ & $\mathrm{RH}, \%$ & \\
\hline Leucaena spp. & $36.67 \pm 3.51$ & $58.67 \pm 3.06$ & $32.2 \pm 1.13$ & $73 \pm 1.41$ & $50.6 \pm 4.45$ \\
\hline Cassia suratensis & $34.33 \pm 1.15$ & $63.00 \pm 3.00$ & $30.5 \pm 0.07$ & $78.2 \pm 0.28$ & $63.7 \pm 5.63$ \\
\hline Areca catecu & $34.67 \pm 4.04$ & $63.00 \pm 6.04$ & $30.2 \pm 1.13$ & $75.5 \pm 0.71$ & $69.6 \pm 6.52$ \\
\hline
\end{tabular}


Based on the research by Sulistyowati (1986), it was found that the effective pollination which was carried out by insects Forcipomyia spp. at 20 populations was 18.8 to $21.3 \%$. Flowers which were visited by Forcipomyia spp. reached 50 to $80.2 \%$ (Adjaloo \& Oduro, 2013). Insects Forcipomyia spp. lives and grows in cocoa farms.

There are many insects Forcipomyia spp. in particular during the rainy season in December to January. Unlike the situation in Ghana, fluctuations of the population insect Forcipomyia spp. has been reported by Glendining (1972), that the pollinators appeared in April-May and the number will increase in October, and the number will stable until the end of the year in line with the coming of the rainy season. In Ghana, the population will drop dramatically with the coming of the harmattan (dry, dusty wind that blows into the forest area in a short time and usually in January), and the population continue to decline during the dry season.
Table 3. showed the monthly fluctuation of Forcipomyia population number on each shade tree farm system. The lowest number of Forcipomyia was on October 2015 (dry seaseon, rainfall was $5.5 \mathrm{~mm} /$ month). Meanwhile, the number of Forcipomyia showed no significant different among three shade trees. On the other hand, the highest number of Forcipomyia spp. was on January 2016 (wet season, rainfall $>200 \mathrm{~mm} / \mathrm{month}$ ). Number of pollinator on Leucaena spp. was significantly higher $26.0-39.1 \%$ than others. In general, number of pollinator insect in Leucaena spp. was $20-40 \%$ higher than Cassia surattensis and Areca catechu.

Activities of Forcipomyia spp. are associated with the substrate of the litter produced by the shade trees or plant biomass that is utilized as the breeding ground (Young, 1982; Frimpong et al., 2011). However, insect pollinators depend largely on the management and plantation management. In Costa Rica was reported that the main breeding

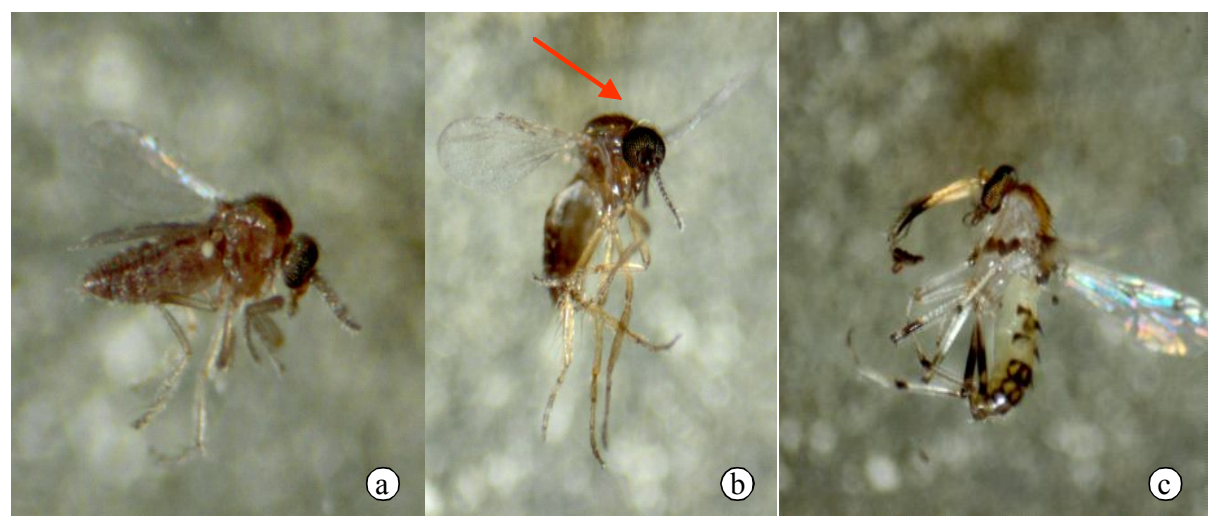

Figure 1. Insect pollinators Forcipomyia spp. trapped: female insects looks aside (a); looks ahead (red arrows indicate the insect thorax section which serves to place pollen attachment) (b); male insects (c)

Table 3. Fluctuation of Forcipomyia spp. population under different shade trees on September 2015-February 2016 (Data \pm Deviation Standart)

\begin{tabular}{|c|c|c|c|c|c|c|}
\hline Shade trees & September & October & November & December & January & February \\
\hline Leucaena spp. & $32.1 \pm 10.03 \mathrm{a}$ & $9.4 \pm 3.78 \mathrm{a}$ & $14.6 \pm 5.73 a$ & $21.63 \pm 6.45 \mathrm{a}$ & $47.3 \pm 10.98 \mathrm{a}$ & $36.4 \pm 10.86 \mathrm{a}$ \\
\hline Cassia surattensis & $21.8 \pm 6.63 \mathrm{~b}$ & $10.5 \pm 4.70 \mathrm{a}$ & $10.8 \pm 3.89 \mathrm{ab}$ & $14.4 \pm 5.56 \mathrm{~b}$ & $35.0 \pm 9.67 \mathrm{~b}$ & $31.3 \pm 10.89 \mathrm{a}$ \\
\hline Areca catechu & $17.0 \pm 8.12 \mathrm{~b}$ & $10.0 \pm 3.46 \mathrm{a}$ & $7.2 \pm 3.21 \mathrm{~b}$ & $19.97 \pm 7.34 \mathrm{ab}$ & $28.8 \pm 8.76 b$ & $23.0 \pm 13.45 \mathrm{ab}$ \\
\hline
\end{tabular}


grounds are likely rotten fruits. Its population is abundant in the dry season, and the number is higher in the forest habitat than in the plantation habitat. Higher pollination activity takes place in a lush shade conditions (Young, 1986). Winder (1978) showed that some types of Forcipomyia breeds in certain media. In Ghana it was reported that Forcipomyia breed in rotting fruits, in the holes of the plant tissue, and branch litter of shade trees. Winder (1978) mentioned that Forcipomyia ashantii Ingram \& Macfie breeds from the litter found between two stands of shade trees, but it still requires further assessment of the media from the litter shade whether it is suitable for breeding sites of the insects.

In this study, cocoa trees should be pruned at the beginning of rainy rainy season and the biomass is placed in that farm. The biomass distributed may be in in forms of garden shade tree pruning, trimmings cocoa, and pod husks of cocoa. Research by Young (1982) revealed that many cocoa insect pollinators breed on litter, especially litter from decays. Availability of litter derived from banana stems, cocoa pod husk and cocoa leaves will increase insect populations are in the cocoa plantation (Young, 1982; Frimpong et al., 2011).

If it looks at the microclimate conditions on the average of the three shade trees, there is not any significant relation with the insect populations. As it shown in Figures 2 and 3, the temperature and relative humidity show little relationship value, 0.08 and 0.04 respectively. This is because there is no relatively large difference in the temperature and humidity in the three shade trees. Similarly, the intensity of sunlight during the observation period showed no association; as the trend is getting brighter and higher light intensity, however, may decrease the insect population (Figure 3)
Insect pollinators Forcipomyia spp. can live on a farm with dynamic temperature and relative air humidity. This is related to the development of each phase of the insects. Forcipomyia in eggs stadium are laid in groups independently from one another (Kaufmann, 1975). At the temperature of $20-25^{\circ} \mathrm{C}$, the egg development range in 2-4 days (Saunders, 1959), and pupae development period at temperature of $20-25^{\circ} \mathrm{C}$ for $2-3$ days (Kaufmann, 1975).

Population of Forcipomyia spp. depends on climatic conditions and seasons of one region. Ibrahim \& Hussein (1987) explained that the suitable microclimate for Forcipomyia spp. to grow and develop and carry out pollination is at the temperature range of $25-35^{\circ} \mathrm{C}$ and the relative humidity of $60-80 \%$; even though microclimate does not affect significantly. Herrera (1995) also showed that the presence of crop insect pollinators L. latifolia types Thymelicus acteon and Fabriciana adippe was not significantly affected by temperature and relative humidity, but significant effect was by intensity of solar radiation.

Implementing good agricultural practices affect abundance of pollinator insect. Some issues that may require spesific attention are planting shade trees and put litter to cocoa plantation system that provide positive effects on microclimate condition and pollinator insect population. In Ghana, planting cocoa and banana trees in multiplecropping system where banana as a temporary shades for mature cocoa trees, showed postive impact on increasing cocoa pollinator insect then increasing cocoa fruit set (Frimpong et al., 2011). Young (1986) explained that shade trees litters had contribution for breeding site for cocoa pollinator insect. Leaf litters of Cassia surattensis and cocoa trees give macronutrients and micronutrients for cocoa plantation system. Leaf litters are potential soil organic material resources on cocoa 


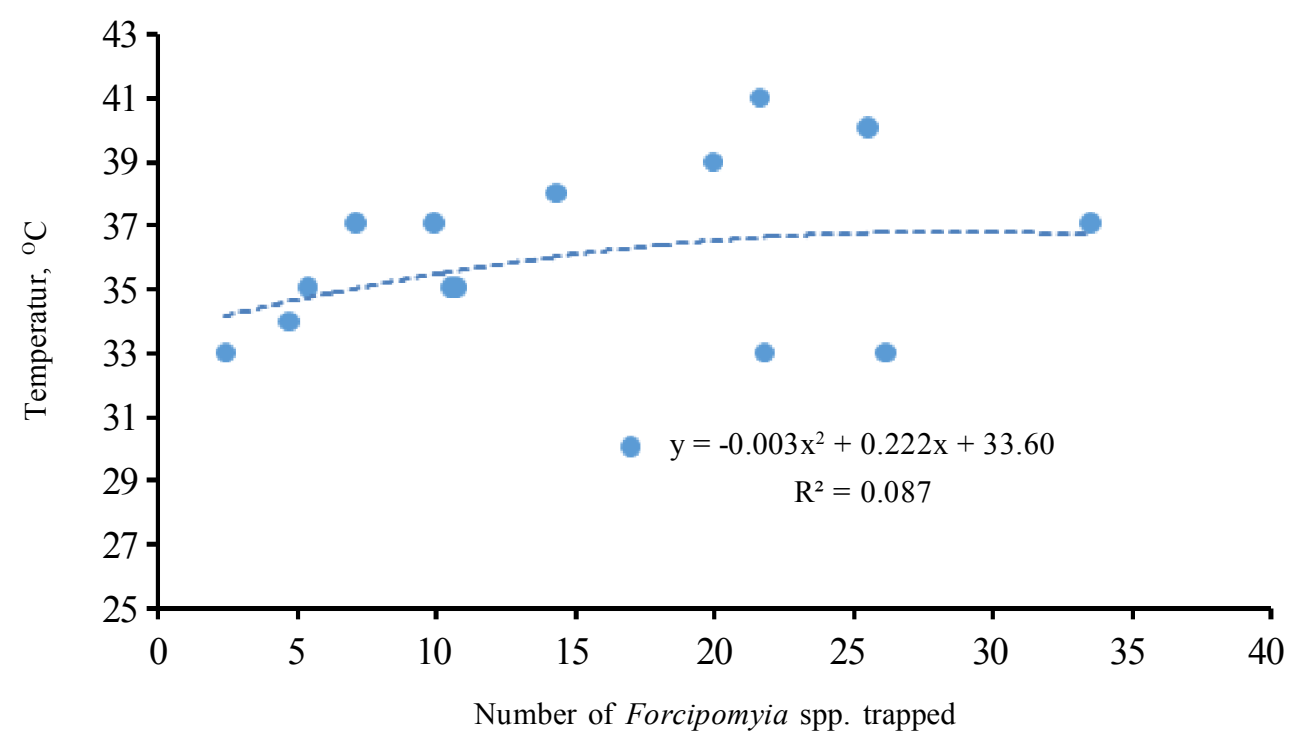

Figure 2. Relationship between temperature and number of insect pollinators

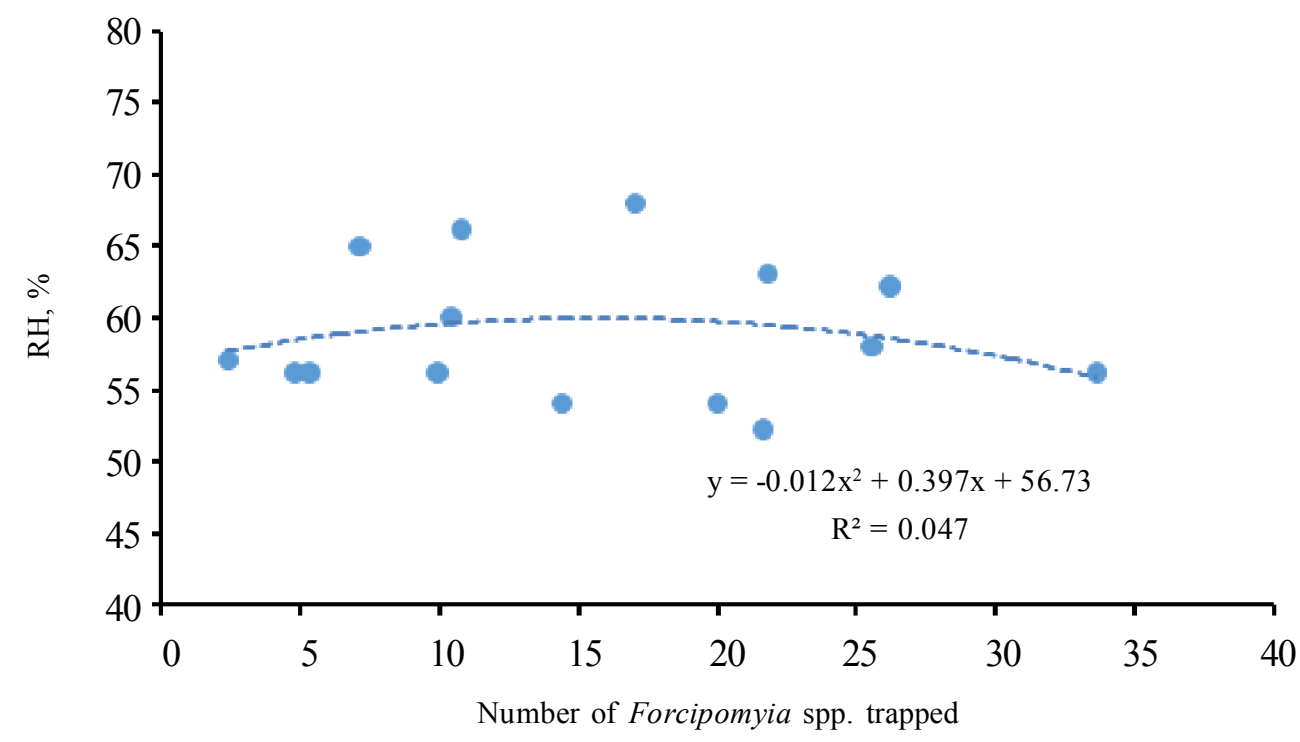

Figure 3. Relationship between RH with total insects trapped 


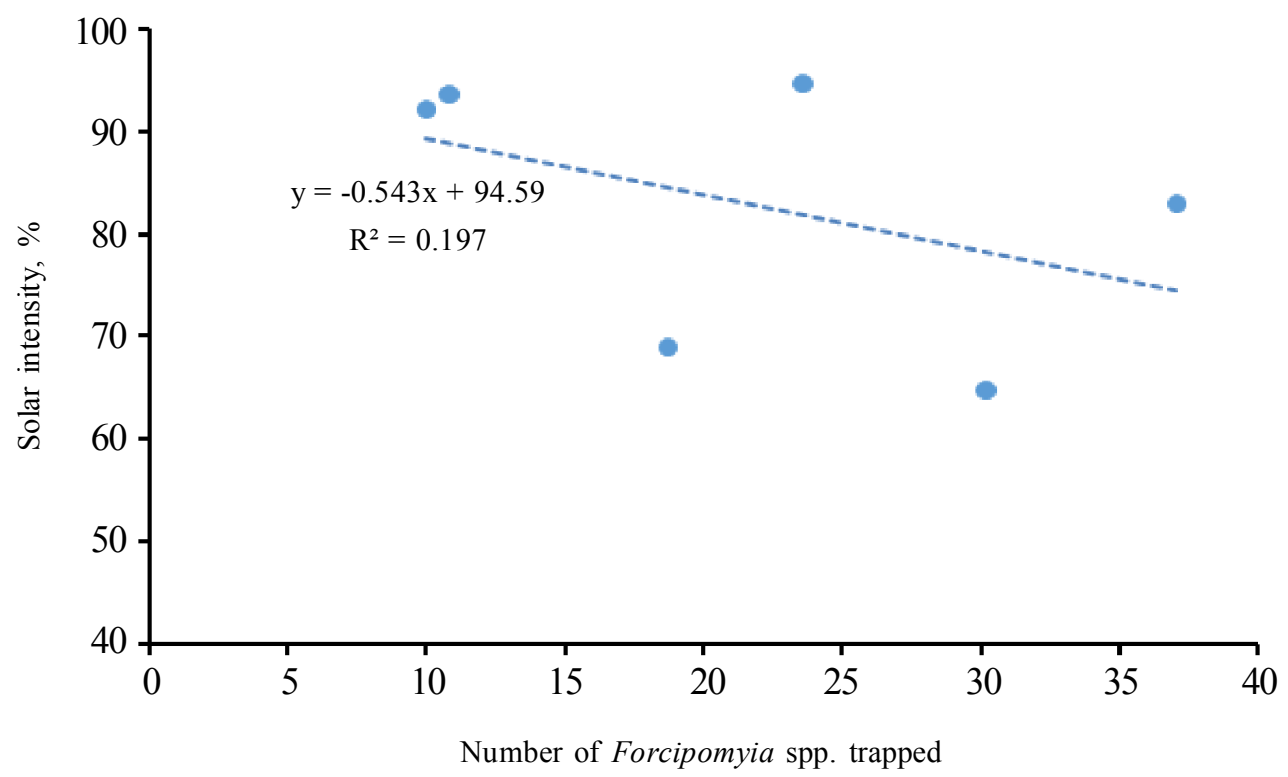

Figure 4. Relationship between solar intensity (\%) with number of insect pollinators

plantation, including shade leaf litters, cocoa leaf litters, cover crop, and others.

\section{CONCLUSION}

The highest population of Forcipomyia spp. was observed on January (in rainy season) under the shade of lamtoro trees which amounted to 47.3 insects per sticky trap. The lowest population was observed on October (in dry season) under all of the observed shade trees. The microclimate condition under all of the observed shade trees cover the variables of temperature, relative humidity and light intensity are not correlated to the population of Forcipomyia spp.

\section{ACKNOWLEDGMENT}

The biggest gratitude is given to Dr. Misnawi, Dr. Agung W. Susilo, Dr. Adi Prawoto, and Prof. Gono Semiadji who have provided supervision and advice in finishing this paper, as well as to Danang and Nurul Hikmah who helped observations during the study period.

\section{REFFERENCES}

Acheampong, K.; P. Hadley \& A.J. Daymond (2013). Photosynthetic activity and early growth of four cacao genotypes as influenced by different shade regimes under West African dry and wet season conditions. Experimental Agriculture, $49,31-42$.

Adjaloo, M.K. \& W. Oduro (2013). Insect assemblage and the pollination system of cocoa (Theobroma cacao L). Applied Biosciences, 62, 4582-4594.

Boreux, V.C.G.; P. Kushalappab; Vaastc \& J. Ghazoula (2013). Interactive effects among ecosystem services and management practices on crop production: Pollination in coffee agroforestry aystems. Proceedings of the National Academy of Sciences of the United States of America, 110, 8387-8392. 
Bos, M.M.; D. Veddeler; A.K. Bogdanski; A-M. Klein; T. Tscharntke; I. SteffanDewenter \& J.M. Tylianakis (2007). Caveats to quantifying ecosystem services: Fruit abortion blurs benefits from crop pollination. Ecological Applications, 17, 1841-1849.

Erwiyono, R.; A.A. Prawoto \& A.S. Murdiyati (2012). Efisiensi resorpsi hara pada tanaman kakao di dataran rendah pada tanah aluvial. Pelita Perkebunan 28, 32-44.

Evizal, R.; Tohari; I.D. Prijambada; I.D. \& D.A.N.J. Widada (2012). Peranan serasah terhadap sumbangan $\mathrm{N}$ dan $\mathrm{P}$ pada agrosistem kopi. Agrotrop, 2, 177-183.

Frimpong, E.; M.K. Adjaloo; P.K. Kwapong \& W. Oduro (2011). Dynamics of insect pollinators as influenced by cocoa production systems in Ghana. Journal of Pollination Ecology, 5, 74-80.

Glendining, D.A. (1972). Natural pollination of cocoa. New Physiologist, 71, 719-729.

Gomez, K.A. \& A.A. Gomez (1984). Statistical Procedures for Agricultural Research. $2^{\text {nd }}$ Edition. John Wiley \& Sons (Eds.). NewYork.

Herrera, C.M. (1995). Microclimate and individual variation in pollinators: Flowering plants are more than their flowers. Ecology, 76, 1516-1524.

Ibrahim, A.G. \& A.M. Hussein (1987). Role of insects in the pollination of cocoa flowers. Pertanika. 10, 103-106.

Kaufmann, T. (1974). Behavioral biology of a cocoa pollinator, Forcipomyia inornatioennis (Diptera, Ceratopogonidae) in Ghana. Review Applied Entomology Series, 63, 1253.

Kaufmann, T. (1975). Studies on the ecology and biology of cocoa pollinator, Forcipomyia squamipennis I. \& M. (Diptera, Ceratopogonidae) in Ghana. Bulletin Entomology Resourcess, 65, 263-268.
Klein, A.-M.; I. Steffan-Dewenter \& T. Tscharntke (2003). Bee pollination and fruit set of Coffea arabica and C. canephora (Rubiaceae). American Journal of Botany, 90, 153-157.

Ngo, H.T.; A.C. Mojica \& L Packer (2011). Coffee plant-pollinator interactions: A review. Canadian Journal of Zoology, 89, 647-660.

Omolaja, S.S.; P. Aikpopodion; S. Adedeji \& D.E. Vwioko (2009). Rainfall and temperature effects on flowering and pollen productions in cocoa. African Crop Science Society, 41-48.

Pias, B. \& P. Guitian (2006). Breeding system and pollen limitation in the masting tree Sorbus aucuparia L. in the NW Iberian Peninsula. Aca Oecoloica, 29, 97-103.

Prawoto, A.A. (2008). Hasil kopi dan siklus hara mineral dari pola tanam kopi dengan beberapa spesies tanaman kayu industri. Pelita Perkebunan, 24, 1-21.

Prawoto, A.A.; A.M. Nur; S.W.A. Soebagiyo \& M. Zaubin (2006). Uji alelopati beberapa spesies tanaman penaung terhadap bibit kopi Arabika (Coffea arabica L .). Pelita Perkebunan, 22, $1-12$.

Prawoto, A.A. \& N.M. Sholeh (2006). Produksi awal dan kajian ekonomis usahatani nilam Aceh (Pogostemon cablin Benth.) sebagai tanaman sela kakao muda. Pelita Perkebunan, 22, 168-190.

Prawoto, A.A.; R. Erwiyono \& A.W. Susilo (2013). Agroforestri kakao dengan tanaman jati dan sengon: Tinjauan siklus nutrisi, kualitas lahan, dan hasil kakao muda. Prosiding Simposium Kakao. Denpasar 28-30 Oktober 2013.

Regazoni, O.; Y. Sugito; A. Suryanto \& A.A. Prawoto (2015). Efisiensi penggunaan energi matahari klon-klon tanaman kakao (Theobroma cacao L.) yang diusahakan di bawah tiga spesies tanaman penaung. Pelita Perkebunan, 31, 21-29. 
Saunders, L.G. (1959). Methods for studying Forcipomyia midges, with sppecial reference to cacao pollinating sppecies (Diptera, ceratopogonidae), Canadian Journal Zoololgy, 37, 33-51.

Scudder, G.G.E. \& R.A. Cannings (2006). The Diptera Families of British Colombia. University of British Colombia. Van Couver, Colombia.

Soria, V. \& S. de J. (1970). Studies on Forcipomyia spp. Midges (Diptera, Ceratopogonidae) Related to the Pollination of Theobroma cacao L., $\mathrm{Ph} . \mathrm{D}$. Thesis. Madison, University of Wisconsin.

Stephenson, A.G. (1981). Flower and fruit abortion: Proximate causes and ultimate functions. Annual Review of Ecology and Systematics, 12, 253-279.

Sulistyowati, E. (1986). Kajian tentang pengaruh padatnya lalu lintas jalan raya terhadap produksi cokelat (Theobroma cacao L.). Menara perkebunan, 54, 41-44.

Thompson, G.M.; S. Jess; A.W. Gordon \& A.K. Murchie (2014). Sticky-trapping biting midges (Culicoides spp.) alighting on cattle and sheep: Effects of trap colour and evidence for host preference. Parasitology Research, 113, 3085-94.
Wahyudi \& Misnawi (2015). Kakao: Sejarah, Botani, Proses Produksi, Pengolahan, dan Perdagangan. UGM Press, Jogjakarta

Winder, J.A. (1978). Cocoa flower Diptera, their identity, pollinating activity and breeding sites. PANS, 24, 5-18.

Young, A.M. (1982). Effects of shade cover and availability of midge breeding sites on pollinating midge populations and fruit set in two cocoa farms. Applied Technology, 19, 47-53.

Young, A.M. (1983). Seasonal differences in abundance and distribution of cocoapollinating midges in relation to flowering and fruit set between shaded and sunny habitats of the La Lola Cocoa Farm in Costa Rica. Applied Ecology, 20, 801-831.

Young, A.M. (1986). Habitat differences in cocoa tree flowering, fruit-set, and pollinator availability in Costa Rica. Journal of Tropical Ecology, 2, 163-186.

$$
* * 0 * *
$$

